\begin{tabular}{|l|l|l|l|l|l|}
\hline J. Tek. Ling & Vol. 12 & No. 3 & Hal. 333 - 343 & Jakarta, September 2011 & ISSN 1441-318X \\
\hline
\end{tabular}

\title{
RESPON PERTUMBUHAN DAN PRODUKSI 4 VARIAN GANYONG (Canna edulis) TERHADAP INTENSITAS NAUNGAN DAN UMUR PANEN YANG BERBEDA
}

\author{
Ning Wikan Utami dan Diyono \\ Bidang Botani, Pusat Penelitian Biologi-LIPI \\ Cibinong Science Center \\ Email:wikan.utami@yahoo.com
}

\begin{abstract}
Abstrak
Ganyong merupakan tanaman yang sederhana dan potensial sebagai sumber karbohidrat, sehingga sangat layak untuk dikembangkan. Kandungan kabohidrat ganyong dibandingkan kandungankabohidrat lebih tinggi dari umbi kentang. Ganyong memiliki variasi morfologi yang luas dalam bentuk tanaman tinggi, warna daun, panjang dan lebar, warna dan bentuk ubi variasi kandungan kimia dalam umbi ganyong, sehingga diperlukan seleksi berdasarkan fenotipe untuk memperoleh varian dari ganyong dengan produktivitas tinggi. Ganyong adalah tanaman yang biasanya tumbuh pada daerah naungan seperti di bawah pohon namun di sisi lain kemampuan pertumbuhannya belum diteliti . Penelitian respons pertumbuhan ganyong 4 varian dalam kondisi iklim mikro yang berbeda telah dilakukan di Laboratorium Macropropagation, Botani Divisi, CSC. Penelitian dilakukan dalam Rancangan Acak Kelompok Faktorial yang terdiri dari 3 faktor di mana faktor 1 adalah shading intensitas: $0 \%$ (tanpa naungan), $50 \%$ dan intensitas varian ganyong $70 \%$ ), faktor 2 adalah ganyong varian (merah, pink, hijau dan putih) sedangkan faktor ke-3 adalah waktu panen (9 dan 11 bulan). Hasil penelitian menunjukkan bahwa setiap faktor yang merupakan bayangan intensitas, varian dan waktu panen berpengaruh nyata terhadap pertumbuhan dan produksi ganyong. Intensitas naungan terbaik adalah $50 \%$ yang secara signifikan berbeda dari $0 \%$ dan $70 \%$ intensitas naungan dalam hal jumlah tunas, berat segar dan berat kering daun dan berat batang, panjang umbi, bobot segar dan kering umbi. Putih varian dari ganyong prodused terpanjang ukuran umbi, bobot segar tertinggi daun dan batang, highst berat segar dan kering umbi dibandingkan dengan varian lain, bahkan dengan 11 bulan waktu panen mengakibatkan umbi tertinggi, berat kering tertinggi umbi, dibandingkan dengan 9 mounths panen. Kombinasi terbaik dari pengobatan adalah putih ganyong varian, $50 \%$ perlakuan yang diberikan adalah pada varian ganyong putih dengan intensitas.naungan $50 \%$ dan waktu perlu 9 bulan mengakibatkan produksi siknifikan seperti diameter umbi terbesar $(4,8 \mathrm{~cm})$, berat segar dan kering umbi highst dari $8454 \mathrm{~g}$ dan $1134 \mathrm{~g} /$ tanaman masing-masing. Kandungan kimia umbi dipengaruhi oleh varian dari ganyong dan waktu panen. Kandungan karbohidrat paling tinggi ditemukan pada 9 waktu panen mounth, sedangkan kandungan serat, lemak dan protein paling tinggi ditemukan pada waktu panen 11 bulan.
\end{abstract}

kata kunci: ganyong, naungan, kultivar, waktu panen, proksimat, pertumbuhan dan produksi 


\begin{abstract}
Ganyong is a crop that is simple and potential as carbohydrate source, so that very competent to be developed. Carbohydrate content of ganyong is higher than potato tuber. Ganyong have broad morphology variation in the form of crop height, leaf color, length and wide, tuber color and shape/appearence and variation of chemical content in the ganyong tuber, so that it is needed to conduct selection based on its phenotype to obtain varian of ganyong with high productivity. Ganyong is crop that usually grows on the shading area such as/like under the tree, on the other hand its growth ability had not been studied yet. This study of growth response of 4 ganyong varian in different microclimate condition had been done in Macropropagation Laboratory, Botani Division, CSC. The study was done in Factorial Randomized Block Design consisting of 3 factors in which the 1st factor was shading intensity : 0\% (without shading), $50 \%$ and $70 \%$ ), 2nd factor was ganyong varian (red, pink, green and white) while the 3rd factor was harvest time ( 9 and 11 month).

The results showed that every factor which were shading intensity, varian and harvest time significantly affected on the growth and production of ganyong. The best shading intensity was $50 \%$ that significantly different from $0 \%$ and $70 \%$ shading intensity in term of number of shoots, fresh and dry weight of leaf and stem, length of corm, the fresh and dry weight of corm. White varian of ganyong prodused the longest of corm size, the heighst fresh weight of leaf and stem, the highst of fresh and dry weight of corm compared to other varians, 11 months of harvest time resulted in the longest corm, the highest dry weight of corm, compared to 9 mounths of harvest. The best combination of treatment was white ganyong varian, 50\% shading intensity and 9 mounths of harvest time which resulted in significantly increasese of production parameters such as the biggest corm diameter $(4,8 \mathrm{~cm})$, the highst fresh and dry weight of corm $8454 \mathrm{~g}$ and 1134 $\mathrm{g} /$ plant respectively. The chemical content of corm was affected by varian of ganyong and harvest time. The highest carbohydrat content was found at 9 mounth harvest time, while the highest fibre, fat and protein content was found at 11 month harvest time.
\end{abstract}

key words: ganyong, shading, cultivar, harvest time, proximate, growth and production

\section{PENDAHULUAN}

\subsection{Latar Belakang}

Kekeringan dan banjir adalah penyebab turunnya produksi beras di Indonesia. Selain itu penyusutan lahan pertanian sebagai lokasi produksi pangan menjadi lokasi pemukiman, perkantoran, jalan dan fasilitas umum lainnya juga mendorong turunnya persediaan beras dalam negeri. Indonesia menjadi pengimpor beras terbesar di dunia. Desakan kultur makan beras membuat masyarakat malu mengonsumsi umbi-umbian. Akibatnya, beras bukan sekadar kebutuhan biologis sumber karbohidrat, tetapi juga simbol status. Hanya mereka yang miskin yang mengonsumsi umbi-umbian. Kultur ini begitu kuat hingga kian memiskinkan masyarakat. Sebab, petani terpaksa menjual umbi-umbian dengan harga amat rendah, untuk membeli beras dengan harga tinggi ${ }^{1}$. Oleh karena itu sudah saatnya kita kembali ke pola diversifikasi pangan dengan memanfaatkan berbagai potensi flora yang ada di Indonesia antara lain ganyong sebagai penghasil pangan. Kandungan karbohidrat pada umbi ganyong lebih tinggi dari pada umbi kentang. Ganyong dapat dipanen pada umur 6 bulan setelah ditanam, namun hasil yang lebih baik jika dipanen pada umur 8 bulan setelah ditanam karena umbinya telah membesar, Namun demikian umur panen pada ganyong sangat tergantung pada curah hujan, dilaporkan bahwa semakin lama dan banyaknya curah hujan maka pembesaran umbi akan semakin lambat 
sehingga umur panen bisa mencapai, 12 bulan ${ }^{2}$. Tanaman ganyong memerlukan curah hujan yang sedang-sedang saja, tidak terlalu tinggi juga tidak terlalu rendah, sehingga tanaman ini dapat hidup dengan baik di musim kemarau atau didaerah kering. Misalnya di Hawai yang curah hujan tahunannya hanya $112 \mathrm{~cm}$, tanaman mampu tumbuh dengan baik dan hasilnya sangat memuaskan ${ }^{3}$. Tanaman ganyong (Canna edulis) yang selama ini dilihat sebelah mata, ternyata bernilai ekonomis. Ganyong merupakan tanaman yang mudah ditanam dan cukup potensial, sehingga sangat layak untuk dikembangkan. Rimpang ganyong ternyata bukan hanya untuk makanan selingan saja, tapi bisa menjadi tepung pengganti tepung terigu ${ }^{4}$. Produksi umbi diperkirakan rata-rata 45 - 50 ton per ha atau $4-10$ ton tepung per ha (Ong \& Siemonsma. 1996) $)^{5}$. Kandungan gizi ganyong tiap $100 \mathrm{gr}$ secara lengkap terdiri dari kalori 95,00 kal, air 75,00 gr, karbohidrat 22,6 gr, protein $1 \mathrm{mg}$, lemak 0,1 g, kalsium $21 \mathrm{mg}$, fosfor $70 \mathrm{mg}$,besi $20 \mathrm{mg}$, vitamin B $0,10 \mathrm{mg}$, vitamin C 10,00 mg, ${ }^{6}$. Sehingga persoalan kandungan gizi tidak perlu tidak perlu dikhawatirkan, karena ganyong juga bergizi. Seorang peneliti pangan dan gizi UGM mengembangkan umbi ganyong (canna edulis) yang bisa dimanfaatkan sebagai makanan alternatif yang murah bagi balita, kandungan kalsium dan fosfor yang besar pada ubi ganyong sangat baik untuk pertumbuhan tulang dan gigi pada balita ${ }^{7}$ Ganyong memiliki varian morfologi yang luas baik dalam bentuk dan tinggi tanaman, panjang dan lebar daun, warna dan bentuk umbi, serta varian kandungan kimia yang berada dalam umbi, sehingga perlu dilakukan seleksi secara fenotipe untuk menemukan varian ganyong/varietas yang berdaya hasil tinggi. Pertumbuhan dan hasil ganyong sangat dipengaruhi oleh kondisi lingkungan tumbuh (mikroklimat) seperti intensitas cahaya, suhu, kelembaban, curah hujan dan kesuburan tanah. Tumbuhan akan memberikan respon terhadap kondisi lingkungan yang tidak sesuai yang disebut dengan stres atau cekaman, anatara lain keterbatasan penerimaan $\left(\right.$ cahaya $^{8}$. Beberapa jenis tanaman mampu tumbuh dan menghasilkan dengan baik bila ternaungi hingga batas tertentu. Berdasarkan kebutuhan cahaya, tanaman diklasifikasikan dalam tanaman cahaya (heliofit) dan tanaman naungan tetapi sebagian besar dapat termasuk dalam keduanya (fakultatif) ${ }^{9}$. Ganyong merupakan tanaman yang dijumpai tumbuh liar di tempat-tempat ternaungi, seperti di bawah pohon pisang, kelapa dan pohon buah-buahan lainnya, di tempat lembab seperti pinggir sawah. Namun sampai sejauh mana kemampuannya tumbuh dalam kondisi ternaungi perlu dipelajari. Naungan berfungsi untuk mengurangi radiasi yang diterima daun dan mengurangi kehilangan air sehingga dehidrasi dapat dihindari ${ }^{10)}$

\subsection{Tujuan Peneltian}

Tujuan dari penelitian ini adalah untuk mengetahui respon pertumbuhan dan produksi 4 varian ganyong terhadap intensitas naungan dan umur panen yang berbeda, serta menentukan umur panen yang tepat dalam kaitannya dengan kandungan kimia umbi

\section{METODOLOGI}

Penelitian respon pertumbuhan dan produksi 4 varian ganyong ganyong (Canna edulis) terhadap intensitas naungan dan umur panen telah dilakukan di kebun percobaan Laboratorium Makropropagasi, Bidang Botani Cibinong Science Center-LIPI. Bahan penelitian berupa umbi ganyong yang diperoleh dari daerah sekitar Pandeglang. Percobaan menggunakan Rancangan Acak Kelompok yang disusun secara faktorial, faktor pertama adalah intensitas naungan terdiri dari 0\% ,tanpa naungan (N0), 50\% (N1) dan $70 \%$ (N2). Faktor kedua adalah ganyong terdiri dari 4 varian yaitu ganyong merah dicirikan dengan umbi berkulit kemerahan dan hijau keunguan (M), ganyong merah strip dicirikan dengan kulit umbi kemerahan dan 
daun hijau dengan stri merah dipinggirnya (Ms), ganyong hijau dicirikan dengan kulit umbi putih kehijauan dan daun hijau $(\mathrm{H})$ dan ganyong putih dengan kulit umbi putih, daun hijau (P). Faktor ketiga yaitu umur panen terdiri dari 9 (P1) dan 11 bulan (P2). Tiap perlakuan terdiri dari 3 ulangan, masingmasing ulangan 3 tanaman. Naungan menggunakan paranet hitam dengan kerapatan yang berbeda. Pada masingmasing naungan dilakukan pengukuran intensitas cahaya dengan alat lux meter , suhu dan kelembaban menggunakan alat thermohygrometer setiap bulan dengan tiga kali pengukuran yaitu pagi jam 08.00, siang jam 12.00 dan sore jam 15.00. Pengamatan parameter pertumbuhan meliputi tinggi tanaman, jumlah daun, panjang dan lebar daun, jumlah anakan, diameter batang dan parameter produksi meliputi diameter dan panjang umbi, bobot segar dan kering umbi, kadar air umbi. Untuk mengetahui tekstur tanah, $\mathrm{pH}$ dan kandungan bahan organik dilakukan analisis tanah kebun tempat penelitian. Pada panen umur panen 9 dan 11 bulan, dilakukan analisa proximat pada umbi untuk mengetahui kandungan kimia pada masing-masing varian ganyong.

\section{HASIL DAN PEMBAHASAN}

Berdasarkan analisis tanah kebun penelitian yang dilakukan di Laboratorium Tanah Departemen IImu Tanah Bogor, diketahui bahwa tekstur tanah adalah liat $77 \%$, debu $19 \%$ dan pasir $4 \%$, p H 5,5 , kandungan bahan organik adalah $\mathrm{N} 0,11 \%$, ,P 73\%, K 4\%, C 1,59\%, ratio C/N 14.

Hasil pengukuran rataan intensitas cahaya, suhu dan kelembaban selama penelitian adalah sebagai berikut:

\subsection{Pertumbuhan tanaman}

Hasil analisa statistik pengaruh masingmasing faktor terhadap peubah pertumbuhan tanaman disajikan pada Tabel 2.

Intensitas naungan berpengaruh nyata terhadap semua peubah yang diamati. Intensitas naungan terbaik adalah 50\% yaitu meningkatkan secara nyata pada semua peubah pertumbuhan yang meliputi ukuran tanaman paling tinggi $(179,66 \mathrm{~cm})$, ukuran daun terlebar $(22,19 \mathrm{~cm})$, jumlah anakan terbanyak ( 22,1$)$, bobot segar tajuk tertinggi ( $4785,8 \mathrm{~g}$ ) dan bobot kering tajuk tertinggi $(392,75 \mathrm{~g})$. Cahaya memegang peranan penting dalam proses fisiologis tanaman, terutama fotosintesis, respirasi, dan transpirasi (Salisbury and Ross 1995)8. Namun demikian kebutuhan akan cahaya matahari biasanya berkaitan dengan habitat alam dari setiap tumbuhan. Ganyong pada umumnya dijumpai tumbuh di tempat yang ternaungi, sehingga tumbuhan ini mampu tumbuh baik pada naungan $50 \%$ dengan intensitas cahaya rata2 23486,67 - 30503,33 Lux, suhu 30,33 - 35,33 0C dan kelembaban 62,67 - 62,67\% (Tabel 1). Hasil analisa statistik menunjukkan bahwa varian ganyong berpengaruh nyata terhadap peubah pertumbuhan seperti tinggi tanaman, jumlah daun dan bobot segar tajuk. Pada Tabel 2 terlihat bahwa ukuran tanaman paling tinggi, jumlah daun terbanyak serta bobot segar tajuk dan kering tertinggi tidak dimiliki oleh varian ganyong tertentu. Varian ganyong ganyong merah

Tabel 1. Rataan intensitas cahaya, suhu dan kelembaban pada berbagai intensitas naungan

\begin{tabular}{|c|c|c|c|c|c|c|}
\hline Naungan & \multicolumn{2}{|c|}{ Intensitas cahaya (Lux) } & \multicolumn{2}{c|}{ Suhu (0C) } & \multicolumn{2}{c|}{ Kelembaban (\%) } \\
\hline & Minimum & Maksimum & Minimum & Maksimum & Minimum & Maksimum \\
\hline $0 \%$ & 37353,33 & 53633,33 & 34,33 & 36,67 & 59,67 & 72,33 \\
\hline $50 \%$ & 23486,67 & 30503,33 & 30,33 & 35,33 & 62,67 & 62,67 \\
\hline $70 \%$ & 6003,33 & 9183,33 & 29 & 34,33 & 65 & 72 \\
\hline
\end{tabular}


strip memiliki ukuran tanaman paling tinggi $(154,35 \mathrm{~cm})$ dan ukuran daun terpanjang $(44,18 \mathrm{~cm})$, varian ganyong ganyong putih memiliki jumlah daun terbanyak $(80,31)$ dan bobot segar tajuk tertinggi $(3523,8 \mathrm{~g})$, varian tinggi tanaman dan panjang daun tidak berbeda nyata pada semua perlakuan. Kombinasi perlakuan ganyong putih dengan naungan $50 \%$ menghasilkan tanaman dengan ukuran paling tinggi yaitu 194,33

Tabel. 2. Pengaruh masing-masing faktor intensitas naungan, varian ganyong dan umur panen terhadap pertumbuhan umbi ganyong

\begin{tabular}{|c|c|c|c|c|c|c|c|}
\hline Faktor & $\begin{array}{l}\text { Tinggi tn } \\
(\mathrm{cm})\end{array}$ & $\begin{array}{l}\text { Jmlh } \\
\text { daun }\end{array}$ & $\begin{array}{l}\text { Panjang } \\
\text { daun } \\
\text { (cm) }\end{array}$ & $\begin{array}{l}\text { Lebar } \\
\text { daun } \\
(\mathrm{cm})\end{array}$ & $\begin{array}{c}\text { Jmlh } \\
\text { anakan }\end{array}$ & $\begin{array}{l}\text { Bobot } \\
\text { segar tajuk } \\
\text { (g) }\end{array}$ & $\begin{array}{c}\text { Bobot } \\
\text { kering } \\
\text { tajuk }(\mathrm{g})\end{array}$ \\
\hline $\begin{array}{l}\text { Intens it a s } \\
\text { Naungan } \\
0 \% \\
50 \% \\
70 \% \\
\end{array}$ & $\begin{array}{lll}111,74 & c \\
179,66 & a \\
143,87 & b \\
\end{array}$ & \begin{tabular}{|ll}
43,23 & $c$ \\
64,87 & $b$ \\
80,47 & $a$ \\
\end{tabular} & $\begin{array}{ll}39,68 & \mathrm{~b} \\
43,70 & \mathrm{a} \\
43,78 & \mathrm{a} \\
\end{array}$ & $\begin{array}{r}19,10 \text { c } \\
22,19 \text { a } \\
20,85 \text { b } \\
\end{array}$ & $\begin{array}{ll}12,29 & b \\
22,5 & a \\
8,07 & b \\
\end{array}$ & \begin{tabular}{|ll}
2130,8 & $b$ \\
4785,8 & $a$ \\
1213,7 & $c$ \\
\end{tabular} & \begin{tabular}{|l|}
274,00 \\
392,75 \\
176,53 \\
\end{tabular} \\
\hline $\begin{array}{l}\text { Varian ganyong } \\
\text { Merah } \\
\text { Merah strip } \\
\text { Hijau } \\
\text { Putih }\end{array}$ & $\begin{array}{ll}142,76 & a b \\
154,35 & a \\
149,96 & a \\
137,46 & b\end{array}$ & $\begin{array}{ll}52,68 & b \\
53,10 & b \\
64,36 & b \\
80,31 & a\end{array}$ & $\begin{array}{ll}41,11 & \text { a } \\
44,18 & \text { a } \\
43,49 & \text { a } \\
41,30 & \text { a }\end{array}$ & $\begin{array}{ll}20,34 & \text { a } \\
21,25 & \text { a } \\
21,31 & \text { a } \\
20,21 & \text { a }\end{array}$ & $\begin{array}{l}10,20 \text { a } \\
12,10 \text { a } \\
18,82 \text { a } \\
16,62 \text { a }\end{array}$ & $\begin{array}{ll}2249,5 & b \\
2640,4 & a b \\
2497,5 & b \\
3523,8 & a\end{array}$ & $\begin{array}{ll}88,33 & a \\
86,04 & a \\
87,83 & a \\
86,69 & a\end{array}$ \\
\hline $\begin{array}{l}\text { Umur panen } \\
9 \mathrm{bln} \\
11 \mathrm{bln}\end{array}$ & $\begin{array}{l}156,69 \text { a } \\
138,39 \text { b }\end{array}$ & $\begin{array}{ll}4,167 & b \\
7,789 & a\end{array}$ & $\begin{array}{ll}44,90 & a \\
40,80 & b\end{array}$ & $\begin{array}{l}21,96 \text { a } \\
19,95 \text { b }\end{array}$ & $\begin{array}{l}12,42 \text { a } \\
15,72 \text { a }\end{array}$ & $\begin{array}{ll}3186,7 & a \\
2471,7 & \text { b }\end{array}$ & $\begin{array}{l}286,44 \text { a } \\
281,51 \text { a }\end{array}$ \\
\hline
\end{tabular}

Keterangan: angka-angka yang diikuti dengan huruf yang sama pada kolom yang sama tidak berbeda nyata pada uji Duncan taraf $5 \%$

ganyong ganyong hijau memiliki jumlah anakan terbanyak $(18,82)$. Umur panen berpengaruh nyata terhadap parameter pertumbuhan seperti tinggi tanaman, jumlah daun, panjang dan lebar daun, bobot segar tajuk. Umur panen 9 bulan menghasilkan daun dengan ukuran lebih panjang (44,90 $\mathrm{cm})$ dan lebih lebar $(21,96 \mathrm{~cm})$, ukuran tanaman lebih tinggi $(156,69 \mathrm{~cm})$, juga bobot segar tajuk nyata lebih tinggi $(3186,7$ g) dan berbeda nyata dengan umur panen 11 bulan, Namun umur panen 11 bulan menghasilkan jumlah daun lebih banyak $(72,789)$ dibandingkan umur panen 9 bulan $(48,167)$ dan berbeda nyata. Hasil ini menunjukkan bahwa pada tanaman ganyong setelah umur 9 bulan pertumbuhan vegetatif mulai melambat, karena sudah mulai masa pertumbuhan dan perkembangan umbi.

Pada tabel 3 nampak bahwa peubah cm, jumlah daun terbanyak $(101,00)$ dan jumlah anakan terbanyak (25) dan berbeda nyata dengan perlakuan lain. Lebar daun $16,44-24,60 \mathrm{~cm}$, ukuran daun terlebar pada naungan $70 \%$, ganyong hijau umur 9 bulan.

Pada umur 11 bulan secara keseluruhan menunjukkan bahwa tinggi tanaman, jumlah daun dan jumlah anakan terbanyak dijumpai pada naungan $50 \%$ untuk semua varian ganyong (Tabel 4). Ukuran tanaman paling tinggi $(207,00 \mathrm{~cm})$ dan jumlah anakan paling banyak $(54,25)$ diperoleh pada ganyong hijau naungan $50 \%$ dan berbeda nyata dengan perlakuan lain.

\subsection{Produksi}

Hasil analisa statistik pengaruh masingmasing faktor terhadap produksi umbi ganyong disajikan pada Tabel 5. 
Pada Tabel 5 teramati bahwa masingmasing faktor yaitu naungan, varian ganyong dan umur panen tidak berpengaruh nyata terhadap tinggi tanaman. Intensitas naungan berpengaruh nyata terhadap panjang umbi, bobot segar dan kering umbi, kadar air umbi. Naungan $50 \%$ menghasilkan produksi umbi basah $(3296,8 \mathrm{~g})$ dan umbi kering $(519,53 \mathrm{~g})$ nyata lebih tinggi dibandingkan naungan $0 \%$ dan $70 \%$. Hasil ini sejalan dengan pertumbuhan ganyong yang terbaik juga pada naungan $50 \%$ yaitu ditunjukkan pada jumlah anakan, bobot setiap tumbuhan. Ganyong pada umumnya dijumpai tumbuh di tempat yang ternaungi pohon besar, sehingga tumbuhan ini mampu tumbuh baik dan menghasilkan umbi maksimal pada naungan $50 \%$ dengan rataan intensitas cahaya, suhu dan kelembaban disajikan pada Tabel 1.

Hasil analisis statistik menunjukkan bahwa varian ganyong berpengaruh nyata terhadap peubah produksi seperti bobot basah dan kering umbi. Varian ganyong ganyong putih menghasilkan bobot segar

Tabel 3. Pengaruh kombinasi perlakuan terhadap pertumbuhan tanaman ganyong umur 9 bulan

\begin{tabular}{|c|c|c|c|c|c|c|}
\hline Naungan & $\begin{array}{l}\text { Varian } \\
\text { ganyong } \\
\text { Ganyong }\end{array}$ & $\begin{array}{l}\text { Tinggi tn } \\
(\mathrm{cm})\end{array}$ & $\begin{array}{l}\text { Jumlah } \\
\text { daun }\end{array}$ & $\begin{array}{c}\text { Panjang } \\
\text { daun }(\mathrm{cm})\end{array}$ & $\begin{array}{l}\text { Lebar daun } \\
\quad(\mathrm{cm})\end{array}$ & $\begin{array}{c}\text { Jmlh } \\
\text { anakan }\end{array}$ \\
\hline $0 \%$ & $\begin{array}{l}\text { Merah } \\
\text { Merah strip } \\
\text { Hijau } \\
\text { Putih }\end{array}$ & $\begin{array}{ll}129,67 & \text { a } \\
116,33 & \text { a } \\
119,33 & \text { a } \\
123,00 & \text { a }\end{array}$ & $\begin{array}{ll}42,33 & \text { a } \\
34,00 & \text { a } \\
37,00 & \text { a } \\
53,67 & \text { a }\end{array}$ & $\begin{array}{ll}37,50 & \text { a } \\
39,20 & \text { a } \\
39,83 & \text { a } \\
39,97 & \text { a }\end{array}$ & $\begin{array}{cc}20,60 & a \\
20,23 & a \\
20,27 & a \\
18,77 & a b\end{array}$ & $\begin{array}{cc}8,67 & b \\
8,00 & b \\
9,33 & a b \\
13,00 & a\end{array}$ \\
\hline $50 \%$ & $\begin{array}{l}\text { Merah } \\
\text { Merah strip } \\
\text { Hijau } \\
\text { Putih }\end{array}$ & $\begin{array}{ll}193,00 & \text { a } \\
174,00 & \text { a } \\
185,67 & \text { a } \\
194,33 & \text { a }\end{array}$ & $\begin{array}{ll}42,33 & b \\
58,67 & b \\
59,00 & b \\
101,00 & a\end{array}$ & $\begin{array}{ll}44,67 & \text { a } \\
49,27 & \text { a } \\
49,40 & \text { a } \\
46,43 & \text { a }\end{array}$ & $\begin{array}{ll}23,23 & a \\
22,37 & a \\
22,37 & a \\
23,50 & a\end{array}$ & $\begin{array}{rr}15,33 & a b \\
21,67 & a \\
18,00 & a \\
25,00 & a\end{array}$ \\
\hline $70 \%$ & $\begin{array}{l}\text { Merah } \\
\text { Merah strip } \\
\text { Hijau } \\
\text { Putih }\end{array}$ & $\begin{array}{ll}162,67 & \text { a } \\
166,00 & a \\
168,00 & a \\
148,33 & \text { a }\end{array}$ & $\begin{array}{ll}37,00 & \text { a } \\
36,67 & \text { a } \\
31,00 & \text { a } \\
45,33 & \text { a }\end{array}$ & $\begin{array}{ll}46,43 & \text { a } \\
46,97 & \text { a } \\
51,97 & \text { a } \\
47,17 & \text { a }\end{array}$ & $\begin{array}{ll}22,20 & \text { a } \\
21,93 & \text { a } \\
24,60 & \text { a } \\
22,67 & \text { a }\end{array}$ & $\begin{array}{ll}8,33 & a \\
8,33 & a \\
6,33 & \text { a } \\
7,00 & \text { a }\end{array}$ \\
\hline
\end{tabular}

Keterangan: angka-angka yang diikuti dengan huruf yang sama pada kolom yang sama tidak berbeda nyata pada uji Duncan taraf $5 \%$

segar dan kering tajuk yang berbeda nyata terhadap naungan $0 \%$ dan $50 \%$ (Tabel 2 ).

Intensitas cahaya yang dibutuhkan tumbuhan cukup beragam, ada tanaman yang membutuhkan cahaya matahari penuh dan ada tanaman yang tidak tahan terhadap cahaya yang berlebih. Intensitas cahaya rendah menurunkan hasil tanaman. Energi yang dikandung oleh radiasi matahari memegang peranan penting dalam proses fotosintesa karena itu produksi tanaman selalu dibatasi oleh ketersediaan radiasi matahari ${ }^{11)}$. Namun demikian kebutuhan akan cahaya matahari biasanya berkaitan dengan habitat alam dari dan kering umbi tertinggi dibandingkan varian ganyong lain yaitu berturut-turut 2812,2 g dan 3523,8 g (Tabel 5). Kadar air umbi tidak berbeda nyata antar varian ganyong, namun ganyong merah memiliki kadar air relatif lebih tinggi dibandingkan varian ganyong lain yaitu $88,33 \%$.

Umur panen berpengaruh nyata pada panjang umbi, bobot segar umbi dan kadar air umbi. Umur panen 9 bulan menghasilkan bobot segar $(2374,5 \mathrm{~g})$ dan kadar air $(87 \%)$ nyata lebih tinggi dibandingkan umur 11 bulan yaitu berturut-turut 1650,4 g/rumpun dan $80 \%$. Sedangkan bobot kering umbi 
Tabel 4. Pengaruh kombinasi perlakuan terhadap pertumbuhan tanaman ganyong umur 11 bulan

\begin{tabular}{|c|c|c|c|c|c|c|}
\hline Naung an & $\begin{array}{c}\text { Varian } \\
\text { ganyong } \\
\text { Ganyong }\end{array}$ & $\begin{array}{l}\text { Tinggi tn } \\
(\mathrm{cm})\end{array}$ & $\begin{array}{c}\text { Jumlah } \\
\text { daun }\end{array}$ & $\begin{array}{c}\text { Panjang } \\
\text { daun }(\mathrm{cm})\end{array}$ & $\begin{array}{l}\text { Lebar daun } \\
\quad(\mathrm{cm})\end{array}$ & $\begin{array}{l}\text { Jumlah } \\
\text { anakan }\end{array}$ \\
\hline $0 \%$ & $\begin{array}{l}\text { Merah } \\
\text { Merah strip } \\
\text { Hijau } \\
\text { Putih }\end{array}$ & $\begin{array}{cc}87,60 & b \\
114,33 & a b \\
91,00 & b \\
127,17 & a\end{array}$ & $\begin{array}{ll}53,60 & b \\
65,67 & b \\
73,00 & b \\
113,33 & a\end{array}$ & $\begin{array}{cc}38,74 & a b \\
36,70 & b \\
39,98 & a b \\
42,83 & a\end{array}$ & $\begin{array}{c}16,44 \mathrm{~b} \\
18,77 \mathrm{ab} \\
18,72 \mathrm{ab} \\
20,09 \mathrm{a}\end{array}$ & $\begin{array}{l}9,200 \quad b \\
13,667 b \\
10,400 b \\
20,83 a\end{array}$ \\
\hline $50 \%$ & $\begin{array}{l}\text { Merah } \\
\text { Merah strip } \\
\text { Hijau } \\
\text { Putih }\end{array}$ & $\begin{array}{cc}165,17 & b \\
184,25 & a b \\
207,00 & a \\
158,67 & b\end{array}$ & $\begin{array}{ll}81,33 & a \\
78,25 & \text { a } \\
111,25 & \text { a } \\
91,00 & \text { a }\end{array}$ & $\begin{array}{ll}38,70 & \text { a } \\
47,15 & \text { a } \\
42,75 & \text { a } \\
39,53 & \text { a }\end{array}$ & $\begin{array}{l}21,65 \text { a } \\
22,83 \text { a } \\
22,36 \text { a } \\
20,42 \text { a }\end{array}$ & $\begin{array}{cc}13,50 & b \\
14,00 & b \\
54,25 & a \\
21,00 & a b\end{array}$ \\
\hline $70 \%$ & $\begin{array}{l}\text { Merah } \\
\text { Merah strip } \\
\text { Hijau } \\
\text { Putih }\end{array}$ & $\begin{array}{ll}136,80 & \text { a } \\
159,50 & \text { a } \\
149,25 & \text { a } \\
92,40 & \text { a }\end{array}$ & $\begin{array}{ll}39,20 & \text { a } \\
41,00 & \text { a } \\
56,25 & \text { a } \\
52,40 & \text { a }\end{array}$ & $\begin{array}{cc}43,22 & a b \\
44,63 & a \\
40,58 & b \\
35,80 & c\end{array}$ & $\begin{array}{l}19,88 \text { a } \\
20,35 \text { a } \\
20,73 \text { a } \\
17,52 \text { a }\end{array}$ & $\begin{array}{ll}6,20 & a \\
7,75 & \text { a } \\
11,00 & \text { a } \\
9,20 & \text { a }\end{array}$ \\
\hline
\end{tabular}

Keterangan: angka-angka yang diikuti dengan huruf yang sama pada kolom yang sama tidak berbeda nyata pada uji Duncan taraf $5 \%$.

Tabel 5. Pengaruh intensitas naungan, varian ganyong dan umur panen terhadap produksi umbi ganyong

\begin{tabular}{|c|c|c|c|c|}
\hline Faktor & $\begin{array}{l}\text { Diameter umbi } \\
(\mathrm{cm})\end{array}$ & $\begin{array}{c}\text { Bobot segar umbi } \\
\text { (g) }\end{array}$ & $\begin{array}{l}\text { Bobot kering } \\
\text { umbi (g) }\end{array}$ & $\begin{array}{l}\text { Kadar air } \\
\text { umbi(\%) }\end{array}$ \\
\hline $\begin{array}{l}\text { Naungan } \\
0 \\
50 \\
70 \\
\end{array}$ & $\begin{array}{ll}4,06 & a \\
4,00 & a \\
3,56 & a \\
\end{array}$ & $\begin{array}{ll}1260,0 & b \\
3296,8 & a \\
1166,6 & b\end{array}$ & $\begin{array}{ll}191,58 & b \\
519,53 & a \\
198,63 & b\end{array}$ & $\begin{array}{l}83,93 \text { a } \\
83,79 \text { a } \\
81,66 \text { b }\end{array}$ \\
\hline $\begin{array}{l}\text { Varian ganyong } \\
\text { Merah } \\
\text { Merah strip } \\
\text { Hijau } \\
\text { Putih }\end{array}$ & $\begin{array}{ll}3,55 & \text { a } \\
3,53 & \text { a } \\
5,01 & \text { a } \\
3,50 & \text { a }\end{array}$ & $\begin{array}{ll}1525,6 & b \\
1455,3 & b \\
1781,4 & b \\
2812,2 & a\end{array}$ & $\begin{array}{cc}254,96 & \mathrm{cb} \\
189,90 & \mathrm{c} \\
283,05 & \mathrm{~b} \\
466,31 & \mathrm{a}\end{array}$ & $\begin{array}{l}83,20 \text { a } \\
85,42 \text { b } \\
82,66 \text { a } \\
81,76 \text { a }\end{array}$ \\
\hline $\begin{array}{l}\text { Umur panen } \\
9 \text { bln } \\
11 \text { bln }\end{array}$ & $\begin{array}{ll}3,76 & a \\
3,95 & a\end{array}$ & $\begin{array}{ll}2374,5 & a \\
1650,4 & b\end{array}$ & $\begin{array}{ll}296,86 & a \\
312,91 & a\end{array}$ & $\begin{array}{l}87,44 \text { a } \\
80,43 \text { b }\end{array}$ \\
\hline
\end{tabular}

Keterangan: angka-angka yang diikuti dengan huruf yang sama pada kolom yang sama tidak berbeda nyata pada uji Duncan taraf $5 \%$.

tidak berbeda nyata, namun pada umur panen 11 bulan cenderung memiliki angka lebih tinggi $(312,91 \mathrm{~g})$ dibandingkan umur 9 bulan $(296,86 \mathrm{~g})$ (Tabel 5). Hal ini dapat dijelaskan bahwa semakin bertambah umur pada tanaman berumbi maka kandungan pati akan semakin meningkat dan kadar air semakin menurun. Menurut ${ }^{2}$ bahwa masa panen umbi ganyong dipengaruhi oleh beberapa faktor antara lain ketinggian tempat tumbuhnya, curah hujan dan kesuburan tanah, hal ini berkaitan dengan pendewasaan umbinya. Berdasarkan hasil analisa kesuburan tanah tempat percobaan 
menunjukkan bahwa kadar liat $77 \%$ dan pasir $4 \%$ yang mengindikasikan bahwa termasuk jenis tanah liat sehingga pertumbuhan dan perkembangan umbi kurang maksimal.

Pada Tabel 6 teramati bahwa kombinasi perlakuan ganyong putih dan naungan $50 \%$ menghasilkan diameter umbi terbesar $(4,80$ $\mathrm{cm})$, bobot basah $(8454 \mathrm{~g})$ dan kering umbi $(1134,7 \mathrm{~g})$ terbesar dan berbeda nyata dengan perlakuan lainnya. Hal ini sesuai dengan pengaruh masing-masing faktor terhadap produksi umbi, dimana naungan $50 \%$ memberikan hasil yang terbaik dan varian ganyong ganyong putih yang menghasilkan umbi tertinggi (Tabel 5), sehingga kombinasi dua perlakuan tersebut akan saling mendukung dan berpengaruh nyata terhadap hasil umbi.

Sama halnya pada umur panen 9 bulan, pada Tabel 7 terlihat bahwa hasil umbi basah dan kering tertinggi diperoleh pada kombinasi perlakuan ganyong putih dengan naungan umbi $74 \mathrm{~g}-1134 \mathrm{~g}$. Pada Tabel 6 dapat dilihat bahwa kombinasi perlakuan terbaik adalah naungan $50 \%$, ganyong putih, umur panen 9 bulan menghasilkan bobot segar dan kering umbi tertinggi yaitu berturut-turut $8454 \mathrm{~g}$ dan $1134,7 \mathrm{~g}$.

Pada berbagai intensitas naungan $(0 \%$, $50 \%$ dan $70 \%$ ) varian ganyong ganyong putih menghasilkan bobot segar umbi (Gambar 1) dan bobot kering umbi (Gambar 2) tertinggi dibandingkan varian ganyong lainnya baik pada umur panen 9 bulan maupun 11 bulan. Hasil ini mengindikasikan bahwa ganyong putih mempunyai adaptasi yang baik terhadap berbagai intensitas naungan dibandingkan varian ganyong lain.

\subsection{Kandungan kimia umbi}

Untuk mengetahui kandungan kimia pada umbi dilakukan analisa proksimat pada 4 varian ganyong umbi ganyong umur panen 9 dan 11 bulan, dipilih tanaman yang tumbuh

Tabel 6. Pengaruh kombinasi perlakuan terhadap produksi umbi ganyong umur 9 bulan

\begin{tabular}{|c|c|c|c|c|c|}
\hline Naungan & $\begin{array}{c}\text { Varian } \\
\text { ganyong }\end{array}$ & $\begin{array}{l}\text { Diameter } \\
\text { umbi }(\mathrm{cm})\end{array}$ & $\begin{array}{l}\text { Bobot segar } \\
\text { umbi (g) }\end{array}$ & $\begin{array}{c}\text { Bobot kering } \\
\text { umbi (g) }\end{array}$ & $\begin{array}{l}\text { Kadar air } \\
\text { umbi(\%) }\end{array}$ \\
\hline $0 \%$ & $\begin{array}{l}\text { Merah } \\
\text { Merah strip } \\
\text { Hijau } \\
\text { Putih }\end{array}$ & $\begin{array}{l}3,20 \text { a } \\
2,90 \text { a } \\
3,33 \text { a } \\
3,23 \text { a }\end{array}$ & $\begin{array}{ll}1029,3 & b \\
1052,7 & b \\
824,7 & b \\
1942,7 & a\end{array}$ & $\begin{array}{ll}101,00 & b \\
100,00 & b \\
100,00 & b \\
258,00 & a\end{array}$ & $\begin{array}{l}88,83 \text { a } \\
89,29 \text { a } \\
87,34 \text { a } \\
87,03 \text { a }\end{array}$ \\
\hline $50 \%$ & $\begin{array}{l}\text { Merah } \\
\text { Merah strip } \\
\text { Hijau } \\
\text { Putih }\end{array}$ & $\begin{array}{l}4,20 \mathrm{~b} \\
4,10 \mathrm{~b} \\
3,80 \mathrm{c} \\
4,80 \mathrm{a}\end{array}$ & $\begin{array}{ll}2453 & b \\
3275 & b \\
3621 & b \\
8454 & a\end{array}$ & $\begin{array}{ll}383,3 & b \\
402,7 & b \\
442,7 & b \\
1134,7 & a\end{array}$ & $\begin{array}{l}84,12 \text { a } \\
87,28 \text { a } \\
87,55 \text { a } \\
85,85 \text { a }\end{array}$ \\
\hline $70 \%$ & $\begin{array}{l}\text { Merah } \\
\text { Merah strip } \\
\text { Hijau } \\
\text { Putih }\end{array}$ & $\begin{array}{l}3,90 \text { a } \\
4,00 \text { a } \\
3,87 \text { a } \\
3,80 \text { a }\end{array}$ & $\begin{array}{l}1014,7 \text { a } \\
1595,3 \text { a } \\
1730,0 \text { a } \\
1502,0 \text { a }\end{array}$ & $\begin{array}{cc}74,00 & b \\
152,00 & a b \\
180,67 & a b \\
233,33 & a b\end{array}$ & $\begin{array}{l}92,67 \text { a } \\
88,44 \text { a } \\
86,44 \text { a } \\
84,48 \text { a }\end{array}$ \\
\hline
\end{tabular}

Keterangan: angka-angka yang diikuti dengan huruf yang sama pada kolom yang sama tidak berbeda nyata pada uji Duncan taraf $5 \%$.

$50 \%$ yaitu berturut turut $3182 \mathrm{~g}$ dan $638,5 \mathrm{~g}$ dan berbeda nyata dengan perlakuan lain. Diameter umbi tidak berbeda nyata pada semua naungan dan varian ganyong.

Bobot segar umbi bervarian yaitu berkisar $724,8 \mathrm{~g}-8454 \mathrm{~g}$ dan bobot kering pada intensitas naungan $50 \%$ karena berdasarkan hasil analisa statistik intensitas naungan tersebut yang menghasilkan umbi paling tinggi. Analisa kandungan kimia umbi ganyong dilakukan di Laboratorium PAU IPB. Hasil analisa proksimat pada umbi 
Tabel 7. Pengaruh kombinasi perlakuan terhadap produksi umbi ganyong umur 11 bulan.

\begin{tabular}{|c|c|c|c|c|c|}
\hline Naungan & $\begin{array}{l}\text { Varian } \\
\text { ganyong }\end{array}$ & $\begin{array}{l}\text { Diameter } \\
\text { umbi }(\mathrm{cm})\end{array}$ & $\begin{array}{c}\text { Bobot segar } \\
\text { umbi (g) }\end{array}$ & $\begin{array}{l}\text { Bobot kering } \\
\text { umbi }(\mathrm{g})\end{array}$ & $\begin{array}{l}\text { Kadar ai } \\
\text { umbi(\%) }\end{array}$ \\
\hline \multirow{4}{*}{$0 \%$} & Merah & $3.326 a$ & $828,4 \quad b$ & $184,40 \quad$ a & 77,79 व \\
\hline & Merah strip & $2.973 \mathrm{a}$ & $912,7 \quad b$ & 185,33 a & 79,24 b \\
\hline & Hijau & 8.514 a & $1107,0 \mathrm{~b}$ & 216,00 a & $80,53 b$ \\
\hline & Putih & $3.273 \mathrm{a}$ & 2016,3 a & 284,00 a & 85,82 \\
\hline \multirow{4}{*}{$50 \%$} & Merah & $3,98 \quad a$ & $2727,0 \mathrm{~b}$ & $495,3 \quad a b$ & 81,96 b \\
\hline & Merah strip & $4,19 \quad a$ & $1424,8 \mathrm{~b}$ & $190,3 \quad b$ & 86,71 a \\
\hline & Hijau & $4,01 \quad a$ & $2734,0 \mathrm{~b}$ & $492,8 \quad a b$ & $81,97 \quad b$ \\
\hline & Putih & 3,45 a & 3182 & $638,5 \quad a$ & 80,03 \\
\hline \multirow{4}{*}{$70 \%$} & Merah & $2,89 \quad$ a & $829,2 \quad$ a & $161,00 \mathrm{ab}$ & 88,44 \\
\hline & Merah strip & $2,98 \quad$ a & $724,8 \quad$ a & $129,25 \quad b$ & $86,44 \quad a$ \\
\hline & Hijau & $4,65 \quad a$ & 1048,5 a & $251,50 a b$ & 84,48 \\
\hline & Putih & 3,02 a & 1246,4 a & $342,20 \quad a$ & 71,72 \\
\hline
\end{tabular}

Keterangan: angka-angka yang diikuti dengan huruf yang sama pada kolom yang sama tidak berbeda nyata pada uji Duncan taraf 5\%

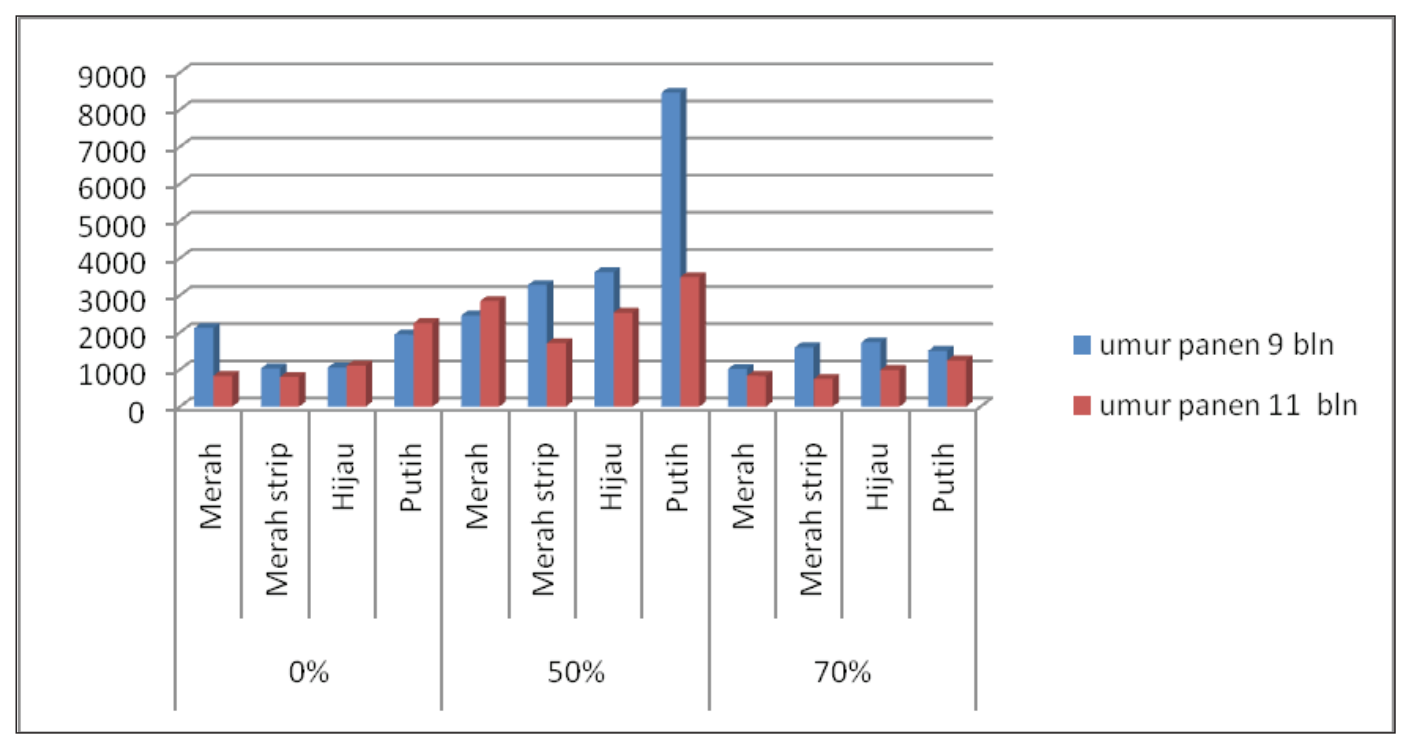

Gambar 1. Bobot segar umbi 4 varian ganyong pada berbagai intensitas naungan dan umur panen yang berbeda

yang meliputi kadar air, abu, lemak, protein, serat kasar dan karbohidrat disajikan pada tabel 8 dan 9.

Pada umur panen 9 bulan (Tabel 8) dan 11 bulan (Tabel 9) nampak bahwa terdapat perbedaan angka pada semua komponen yang diperiksa. Kadar air dan kandungan karbohidrat mengalami penurunan pada semua varian ganyong, sedangkan kadar abu, lemak, protein dan serat kasar mengalami peningkatan. Kondisi ini dapat diterangkan bahwa dengan bertambahnya umur tanaman sebagian air dan karbohidrat akan mengalami proses metabolisme 


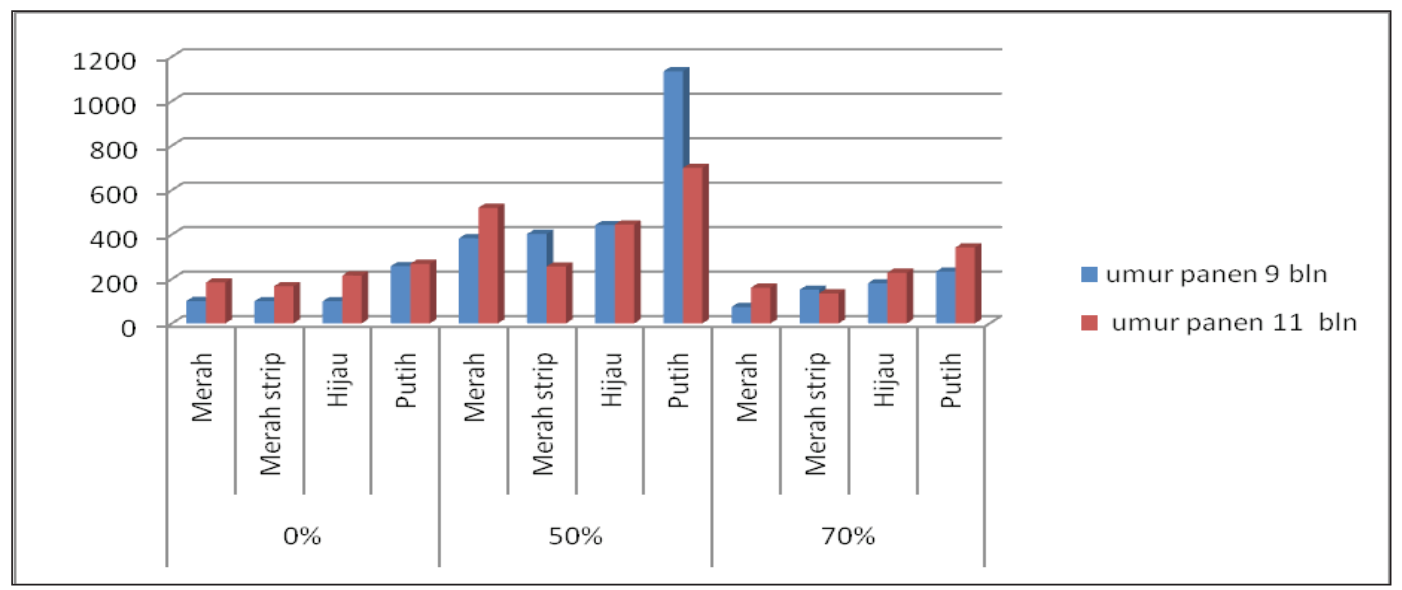

Gambar 2. Bobot kering umbi 4 varian ganyong ganyong pada berbagai intensitas naungan dan umur panen yang berbeda

menjadi komponen lain seperti serat, abu dan lain-lain. Dari hasil penelitian ini dapat disarankan bahwa sebagai bahan pangan sumber karbohidrat sebaiknya umbi dipanen pada umur 9 bulan karena kandungan karbohidrat lebih tinggi dibandingkan umur 11 bulan. Kandungan karbohidrat berkisar antara 78,57 - 80,62\%, tertinggi pada ganyong merah strip (Tabel 8). Sedangkan untuk tujuan gizi dan kesehatan umur panen 11 bulan cenderung lebih baik karena kandungan serat kasar cukup tinggi yaitu antara $3,10-4,75 \%$, protein $5,12-5,82 \%$, dan lemak $0,32-1,32 \%$, ganyong merah strip memilki kandungan lemak, protein dan serat kasar cenderung lebih tinggi dibandingkan varian ganyong lainnya.

\section{KESIMPULAN:}

1. Intensitas naungan berpengaruh nyata terhadap pertumbuhan dan produksi

Tabel 8 . Hasil analisa proksimat 4 varian ganyong ganyong pada umur panen 9 bulan

\begin{tabular}{|l|c|c|c|c|c|c|}
\hline \multicolumn{1}{|c|}{ Sampel } & $\begin{array}{c}\text { Kadar air } \\
(\%)\end{array}$ & $\begin{array}{c}\text { Abu } \\
(\%)\end{array}$ & $\begin{array}{c}\text { Lemak } \\
(\%)\end{array}$ & $\begin{array}{c}\text { Protein } \\
(\%)\end{array}$ & $\begin{array}{c}\text { Serat kasar } \\
(\%)\end{array}$ & $\begin{array}{c}\text { Karbohidrat } \\
(\%)\end{array}$ \\
\hline Ganyong putih & 14,56 & 1,94 & 0,62 & 3,39 & 0,92 & 78,57 \\
\hline Ganyong Merah & 12,80 & 2,04 & 0,87 & 3,99 & 0,40 & 79,90 \\
\hline Ganyong hijau & 13,08 & 1,69 & 0,32 & 4,10 & 0,39 & 80,42 \\
\hline Ganyong Merah strip & 12,03 & 1,90 & 0,72 & 3,68 & 1,05 & 80,62 \\
\hline
\end{tabular}

Tabel 9. Hasil analisa proksimat 4 varian ganyong ganyong pada umur panen 11 bulan

\begin{tabular}{|l|c|c|c|c|c|c|}
\hline \multicolumn{1}{|c|}{ Sampel } & $\begin{array}{c}\text { Kadar air } \\
(\%)\end{array}$ & $\begin{array}{c}\text { Abu } \\
(\%)\end{array}$ & $\begin{array}{c}\text { Lemak } \\
(\%)\end{array}$ & $\begin{array}{c}\text { Protein } \\
(\%)\end{array}$ & $\begin{array}{c}\text { Serat kasar } \\
(\%)\end{array}$ & $\begin{array}{c}\text { Karbohidrat } \\
(\%)\end{array}$ \\
\hline Ganyong putih & 9,36 & 3,67 & 0,41 & 5,17 & 3,10 & 78,29 \\
\hline Ganyong Merah & 10,43 & 3,43 & 1,32 & 5,80 & 3,56 & 75,46 \\
\hline Ganyong hijau & 10,44 & 3,50 & 0,32 & 5,12 & 3,46 & 77,16 \\
\hline Ganyong Merah strip & 11,61 & 4,61 & 1,31 & 5,82 & 4,75 & 71,90 \\
\hline
\end{tabular}


ganyong, naungan 50\% menghasilkan bobot basah dan kering umbi tertinggi

2. Varian ganyong berpengaruh nyata terhadap pertumbuhan dan produksi ganyong, ganyong putih memiliki bobot basah dan kering umbi tertinggi dan beda nyata dengan varian ganyong lainnya.

3. Umur panen berpengaruh nyata terhadap bobot basah dan kadar air umbi.

4. Kandungan kimia umbi dipengaruhi oleh varian ganyong dan umur panen, Untuk memperoleh kandungan karbohidrat tinggi sebaiknya dipanen umur 9 bulan, sedangkan untuk serat tinggi dan kandungan lemak, protein tinggi lebih baik dipanen umur 11 bulan,

5. Kombinasi perlakuan terbaik adalah intensitas naungan $50 \%$,ganyong putih dan umur panen 9 bulan menghasilkan bobot basah dan kering umbi tertinggi yaitu berturut-turut $8454 \mathrm{~g}$ dan $1134,7 \mathrm{~g}$

\section{UCAPAN TERIMA KASIH}

Penulis mengucapkan terima kasih kepada Sdr. Ir. Sri Rahayu sebagai tenaga honorer, Sdr. Aah dan Sdr. Radi Hidayat Agung teknisi Laboratorium Makropropagasi yang telah membantu dalam pelaksanaan penelitian ini.

\section{DAFTAR PUSTAKA}

1.. Rahardi, F. 2007. Kultur Beras yang Memiskinkan. Kompas 24 Februari 07 dalam

ht t p://kompas, com/kompas cetak/0702/24/opini/3332889,htm (9 Desember 2009)

2. Lingga, P., J.J. Afriastini. B.Sarwono, R. Wudianto, F. Rahardi, W.H. Apriadji. \& .C. Rahardja, 1991. Bertanam Ubiubian. Penebar Swadaya. Jakarta. 285 hal

3. Nuryadin,A., 2008. Budidaya ganyong. http://featikabsinjai.blogspot. com/2008/10/budidaya-ganyong.html (24 Maret 2011)

4. Plantus, 2007. Tanaman Ganyong Bisa Jadi Substitusi Tepung Terigu http://anekaplanta.wordpress. com/2007/12/21/tanaman-ganyongbisa-jadi-substitusi - tepung-terigu/

5. Ong H.C. dan J.S. Siemonsma, 1996. Canna indica L. dalam Plant Resources of South- East Asia No.9 Plants yielding non-seed carbohydrates Ed. M.Flach and F. Rumawas (63-66)

6. Direktorat Gizi, Departemen Kesehatan RI. 2007. Jakarta: Daftar Komposisi Bahan Makanan. Bharata Bina Aksara

7. Dida, 2009, Atasi Gizi Buruk dengan Ubi Ganyong from: bernas,co,id)

http://hmppi angan,org/ index, ph p o p tion = com _ content\&task=view\&id=49,

( 9 Desember 2009)

8. Hong-bo, S.C., Li-ye, Z. Chang-xing, G. Qing-jie, L. Xian-an, R., Jean- Marcel, 2006, Plant gene regulatory network system under abiotic stress, Acta Biology Szegediensis 50 (1-2): 1-9

9. Salisbury F. B. and C.W. Ross 1992. Plant Physiology vol 3 (terj.) ITB bandung

10. Edmond, J.B., Senn, F.S. Andrew and R.G. Halfacre, 1979, Fundamentals of Horticulture Tata Mc Graw-Hill Pub Co, New Delhi, 560 pp

11. Monteith, J.L., 1981.Does light limit crop production, Pp 23-28, In C,B, Johnson (Ed,),Physiological Processes Limiting Plant Productivity, Depart,Of Botany, Univ.of Reading-London 